\title{
Juridical Analysis of Transitional Land Rights Unregistered in Dharmasraya Regency
}

\author{
$1^{\text {st }}$ Ratih Agustin Wulandari \\ Faculty of Law and Business \\ Economics \\ Universitas Dharmas Indonesia \\ Dharmasraya, Indonesia \\ wulandariagustin88@gmail.com \\ $4^{\text {th }}$ Raimon Efendi \\ Faculty of Computer Sciience, \\ Universitas Dharmas Indonesia \\ Dharmasraya, Indonesia
}

\author{
$2^{\text {nd }}$ Mayroza Wiska \\ Faculty of Law and Business \\ Economics \\ Universitas Dharmas Indonesia \\ Dharmasraya, Indonesia \\ $5^{\text {th }}$ Yulia Darniyanti \\ Faculty of Teacher Training and \\ Education \\ Universitas Dharmas Indonesia \\ Dharmasraya, Indonesia
}

\author{
$3^{\text {rd }}$ Wiwik Okta Susilawati \\ Faculty of Teacher Training and \\ Education \\ Universitas Dharmas Indonesia \\ Dharmasraya, Indonesia
}

\begin{abstract}
The purpose of this study is to determine the existence of the transfer of rights to customary land that has not been registered in the Dharmasraya district, how the rights of the people as owners of customary land that have not been registered to the high heritage heirlooms of people who have transitioned rights. This study uses an empirical juridical approach method which is expected to provide a descriptive description. Data collected in this research are primary data and secondary data. Where primary data is obtained directly from the community in the field through interviews, while secondary data is obtained from library research. All data obtained will be analyzed qualitatively.The results of this study indicate the existence of the transfer of customary land rights which have not been registered is getting higher, namely in the form of buying and selling, as evidenced by the existence of ulayat land as a high heritage heirloom where initially the customary land has a social function for its members, but after the transfer of rights in the form of buying and selling is done so that the communal rights of the communal land are lost and the function changes from the original function for social interests to the full rights of the buyer. The rights of the people as the owner of the communal land that has undergone the transfer of rights in the form of buying and selling with a letter of sale and purchase, members of the clan can claim back the communal land that has been bought and sold with that other party, if the transfer of rights is in the form of a grant from the customary owner, then the members of the clan cannot suing the status of land ownership obtained through the transfer of rights on a grant basis.
\end{abstract}

\section{Keywords-Juridial, Land Rights, Dharmasraya}

\section{INTRODUCTION}

Land and the existence of a people are inseparable, both of them are like two sides of a coin. The reflection of a harmonious life as a civil society in accordance with UUD 1945 Constitution can be realized in traditional society. Indonesia's wealth is very diverse both in natural resources and biodiversity. Indonesia's economy depends on the forestry and agriculture sectors, which are the livelihoods of its people.[1]

Good law is a law that lives and grows in society (living law), in the form of habits which are the source of law in accordance with the opinion of Von Savigny with his school of history, that law constitutes historical phenomenon, so the existence of every law is different, depending on the place and time of entry into force of the law, as well law must be seen as the embodiment of a soul or spirit nation. Likewise with the sociological jurisprudence mashab explores the importance of living law. [2] It is undeniable that this view affects customary law in Indonesia.

In the Constitution of 1945 , the state recognized the existence of a customary law society Article 18 B of the Constitution of 1945 states that the State acknowledges and respect the unions of the customary law community its traditional rights are still alive and well the development of the nation, society and the principles of the United Nations Republic of Indonesia regulated by law.

The Humans can be survived of managing land that is very useful for life, as a place to get cloth and food. The Land can make money that can connect human life. It can be the object of a sale and purchase transaction, a mortgage, an object of collateral in a credit agreement it becomes an investment whose price is increasingly.

The Land has strong proof of rights that has been registered with the National Land Agency (BPN) or has been certified. However, there are still many people who 
did not register their land, especially Ulayat Land. Ulayat Land as known 'communal bezitrecht' is a joint owned land where the right is relevant customary law community that controls.

Ethnic groups in the West Sumatra region are called Minangkabau. Minangkabau has a matrilineal or Matriakhat kinship system, which is based on the mother's maternal line, where each child prioritizes their mother's offspring. Women in Minangkabau do not leave their relatives and do not follow their relatives.[3]

The right buying and selling to land that has not been registered has low legal risk. However, this is time there are a lot of buying and selling of customary land that has not been registered, including in the Regency of Dharmasraya. Tenants in Minangkabau consist of: Tribal Land is a tenure owned by a tribe at the discretion of the Chief of Tribes or the Chief of the Heirs of the Heirs. Tribal Land Tenure is the tenure of a tribe owned by the tribe or the head of the tribe. The Land of the districk is tenure of land owned by all the children of the country or of the children of the tribe with the authority of the tribal chiefs of the country concerned [4].

Ulayat land is a high inheritance property of the people, which is a public right, aimed at the people for the sake of the people, which cannot be controlled by people outside the clan. Now, it has experienced a development, in which many of the heirloom treasure lands have been transferred or sold so that they are civil. This is very contrary to the provisions of the Minangkabau customary law which adheres to matrilineal lineage.

\section{METHOD}

This research uses the method of legal sociology which is an approach that analyses how reactions and interactions occur when the norm system works in society. [5] This research is descriptive in nature, meaning that research that provides data on a social situation or symptoms that develops in the midst of the community is in accordance with the facts and without engineering, so that with this research it is expected to obtain a comprehensive picture, complete, and systematic about the object under study.[6] The type of data used to collect information consists of primary data and secondary data. [5] Primary data is obtained from the community in the field, while secondary data from various literatures or related regulations.

\section{RESULT AND DISCUSSION}

The existence of the transfer of customary land rights that have not been registered in the Dharmasraya district.

According to Minangkabau customary law the scope of customary rights cannot be separated between land, water and natural resources contained therein. This is in accordance with the traditional proverb of Minangkabau, namely: sekalian nego hutan tanah, mulai dari batu / pasie nan saincek, rumpuik nan sahalai, jirek nan sabatang, kaatehnyo taambun jantan, ka bawah sampai takasiak bula, pangkek penghulu punyo ulayat.

The ancestors of the Minangkabau people realized that land was the most important part of their lives and their descendants, and therefore generally the high treasure in
Minangkabau was land. Ulayat land is one of the land in question.

Customary land is land that is jointly owned by a certain customary law community or commonly known as tribal land on which there are customary rights or authority to cultivate or utilize customary land which becomes its territory.[7] In principle, everything related to customary land must be with the approval of the head of the heirs and members of the clan as the owner of the customary land. To carry out acts and legal relations with regard to customary land, they are represented by mamak head of inheritance on behalf of his people. In Minangkabau high heirlooms can be mortgaged for the following 4 reasons: Freezing house (leaky house), The dead body is called home (dead body in center), Gypsies (unmarried girls), Raise the bar stems (uphold the title).[8]

The land was inherited from generation to generation, passed down from the ancestors to the next, in unbreakable and indivisible part. As in the customary ruling stating: Babirik-birik tabang ka sawah, Dari sawah tabang ka halaman, Basuo di tanah bato, Dari niniak turun ka mamak, Dari mamak turun ke kamanakan, Patah tumbuah hilang berganti, Pusako baitu juo. [9]

In Indonesia, customary rights are the control of land by the community customs are very diverse. In every customary law community no all of them use the term ulayat rights. Various terms are used in accordance with the criteria of each indigenous community. Customary rights are different from use rights, customary rights are communal while use rights give authority to others to use or use a parcel of land for importance, usually to the paddy fields and fields that have been opened and worked continuously for a long time.[10] Customary rights are more existent than with Indonesian independence, due to customary rights and indigenous and tribal peoples existed before Indonesian independence.[11]

The term about the description of indigenous and tribal peoples in Indonesia various types such as: "petuanan" (Ambon), "panyampeto" (Kalimantan), "wewengkon" (Java), "prabumian" (Bali), "Limpo" (South Sulawesi), "Paer" (Lombok), "Ulayat" (Minangkabau) and others.[12] Djojodigoeno called it "ancient rights" and Supomo called it "Defense rights".

The tenure rights are the highest customary law community. Article 3 The UUPA states that 'the exercise of tenure and similar rights from the customary law societies, as long as they exist, must be so in accordance with national and State concerns, which is based on national unity and cannot be in conflict with higher laws and regulations'. [13]

Conceptual treasures according to Hamka are divided into two, namely: [4] High Heritage Property. Obtained by iron, the term is a philosophy of the Minangkabau people that explains the source of the inheritance itself. In the treasury which is translucent, it means that the inheritance is owned by a family or a family which was obtained by a previous parent from the gift of their ancestors. [5] Low Heritage property, Low heritage is obtained by translating gold, the intention is from the search / purchase by someone or their parents. But the gold treasury heirloom 
will be a high or iron heirloom treasure, if the inheritance is obtained for more than four generations. This treasure has not been intended personally for their children since long time ago. [4]

The transfer of customary land rights is often done in the form of buying and selling, pawning and grants. In the practice of buying and selling communal land, the people in general in the Dharmasraya district, especially in the Koto Baru sub-district, do it underhandedly. In Dharmasraya Regency Ulayat land may only be mortgaged for 5 (five) reasons, namely: (1) If someone dies but the corpse does not have any assets left behind, then the people can sell the high pusako property to cover the cost of carrying out the remains until they are buried. (2) If there is a traditional house belonging to the people that is damaged, then the high pusako land is sold to repair it. (3). If there is a debt of people who are embarrassing the people, then high pusako property land is sold to cover it. (4) Pangangulu Batak Costs. (5). If there is a niece, granddaughter of a group of people who are not yet married, then the land of high pusako property is used to reward a man who wants to marry him.

In this time the reasons for mortgaging communal land have varied, the communal land can be mortgaged for any reason, not only concerning 5 (five) things above. Like the cost of repairing irrigation, the cost of pilgrimage, school fees for children, paying blood or joint debt and others.

In the Minangkabau customary law provisions, Ulayat land can be transferred forever to parties outside the clan if the party is almost extinct. Extinction in customary law in Minangkabau when in a people can no longer be shown inheritance with blood ropes, or in the clan.

Most of the Ulayat land in Dharmasraya Regency did not have strong proof of ownership, registered and certified. The jungle land that is far from the settlements of the people or communities owned and controlled by the Ulayat holders, where all grandchildren of the ancestors of the ulayat holders can work on this land both gardening and farming that is called the ulayat land of the people as high heirloom treasures while the domains, rice fields and fields which is around the village which is controlled for generations by groups within one clan is called ulayat land as a low heirloom treasure.

The practice of buying and selling indigenous peoples' land in the Dharmasraya district consists of Buy and sell a plot of garden and buying and selling a plot of land followed by a customary land grant

In the past, all forms of transfer of customary land rights in Dharmasraya Regency started verbally. In accordance with developments and needs and required by regulations, the transfer of land rights in writing and under the hand. In Dharmasraya District, the transfer of customary land rights is mostly based on the rights signed by the ruling clan. Pursuant to Government Regulation Number 24 of 1997 concerning Land Registration, the base of the right under the hand can be used as the basis for the issuance of certificates and has the power of proof. the basis for the right under the hand does not have legal force but can still be used as a basis for the issuance of a Certificate of Property as long as the data contained therein contains truth. There is a mismatch between customary law and legislation, it can be seen from the land rights that are governed nationally that would conflict with customary law in force in the Minangkabau indigenous community.[14]

The transfer of customary land rights in the form of buying and selling, grants and pawns eventually led to the registration of the land, which naturally shared ownership was increasingly narrowed due to individualization of land. Communal customary land (high inheritance property or low inheritance property) in Dharmasraya district, many have transferred power to migrants or foreign parties and large companies that manage these lands into company plantations (such as PT. Ingkasi Raya, PT Bina, PT AWB), factories and others.

This happened because the mamak head of inheritance supported the transfer of the rights to the company, so that ulayat land which was still in the form of forest, no longer functions socially. That should be the livelihood of the people, and the people can manage their land.[15] The government should limit companies to the practice of land allocation, especially customary land and not prioritize companies and prevent forest land conservation, land grabbing so that there are no land conflicts.[16]

The existence of the transfer of customary land rights that have not been registered is getting higher, namely in the form of buying and selling, as evidenced by the existence of the communal land as a high inheritance property which has initially declined where the communal land has a social function for its members, but after the transfer of rights in the form of the sale and purchase of the communal land are lost and the function changes from its original function to social interests / people become the full rights of the buyer.

The rights of the people as owners of customary land that have not been registered against the high inheritance property of people who have experienced the transfer of rights.

The term beschikkings (hak ulayat) describes the relationship between the community and the land itself, for this legal relationship has since been accepted by the public. According to Van Vollenhoven customary rights are the second pillar of the pillars of law '. As the first pillar is a legal alliance, this can be understood that indeed for the existence of a customary right there must be a legal alliance that claims a certain area or certain area of land as a jointly owned area. [17] Tenure rights are a legal authority custom is owned by a particular customary community over a particular region which is a living environment for its citizens to benefit from natural resources, including land within the region for its survival and survival, which is based on an outward and inward relationship that is not interrupted between the customary hockey community with the territory concerned. [18]

Individual rights to land are different from customary land rights, private rights to land recognize individual freedom to transfer and obtain these rights through economic transactions. This has resulted in indigenous peoples losing their rights. For this reason community 
discretion and community hearings are needed before any transaction takes place.[19]

As long as the land on which there is a communal right, the land must be utilized by the community to improve welfare. Customary rights must be true and followed by the relationship between land and the community. Customary rights that no longer exist cannot be re-inflicted.[20] Basically, customary rights involve legal relations between customary law community with land in their environment which contains authority and obligations towards the land with all its contents, namely waters, plants and animals in the area that is the source of life and livelihood. For this reason ulayata rights include all agrarian resources.[21]

In the UUPA, customary rights consist of 2 aspects, namely the public and civil aspects. [22] The public aspect of customary rights is the authority of the subject of customary rights, which is the authority of members of the customary law community or community itself, consisting of the authority to make plans, inventories, allotment and maintenance of the said customary rights, the authority to regulate legal actions related to customary rights give permission for outsiders or the community itself, utilizing cork from ulayat. Civil aspects where in principle the customary rights are owned by all members of the customary community or community, where the rights cannot be handed over to anyone.

Customary law societies are organized, unified people, living in a particular area, with rulers or inexperienced wealth, where each member of the union is living a natural life according to the natural law and no one among the members it has the mind or tendency to dissolve the growing bond or to leave it in the sense of releasing it forever. [23]

In the traditional philosophy Minangkabau tenure is the power or authority of the customary law community over a particular area or space that is a living environment for its citizens to enjoy the benefits of natural resources for survival arising from their outward and inward relationships, including plants, rocks (minerals) and everything on the ground, such as sea, river, lake, well, valley and land, including space.

The clan can be met with the communal land of the clan, which is the collective right (shared) of the members of the clan concerned not the individual's right, which cannot be transferred permanently, except in a state of urgency. The conditions needed to determine the existence of customary rights include 3 (three) elements, namely: (1) The element of indigenous peoples, namely the presence of a group of people who are still bound by their customary legal arrangements as citizens together with a certain legal alliance, which recognizes and applies the provisions of the community in their daily lives. (2) Regional element, the existence of certain customary land which is the environment of the citizens of the legal alliance and a place to take their daily needs.(3) The element of relationship between certain communities and their territories, namely the existence of customary legal arrangements regarding the management, control and use of customary land that is still valid and adhered to by members of the legal community. [6]

Article 26 paragraph (1) of the BAL provides protection for citizens who actually have land rights, where " buying and selling, exchanging, giving away, giving a will, giving according to custom and other acts intended to transfer ownership and control by government regulations ".

Other parties apart from members of the clan can utilize customary land, but must obtain approval from the leadership and members of the clan, and pay recognition to the owner of the communal land. But now the need for land, especially for agricultural land is increasing, the practice of buying and selling communal land for many people has occurred and is done by members of the clan themselves. Although communal land is the highest right owned by members of the community, in fact the communal land can be transferred to the hands of third parties, both within and outside the clan.

Dharmasraya Regency is communal land of the people has been controlled and owned based on the letter of relinquishment of rights, namely grants, giving of customs or wills (as intended by the LoGA mentioned above) signed by the head of his people (ampek jinih) and known by the Chairman of Customary Density Districk (KAN) along with Wali Nagari, the grandson of the nephew of the customary land authority or other parties outside the community cannot claim back the customary land sold. Conversely, if a high heirloom property that has been sold by a member of the clan to another party does not go through the procedures mentioned above, then the member of the clan or other clan can sue and cancel the sale and purchase, because Ulayat land as a high heirloom property is a joint right (collective) of members of a custom alliance.

The members of the clan can reclaim the customary land that has been transferred, if the transfer of rights is only done with a letter of sale and purchase, because they do not yet have full mastery rights, as usually written in a letter of sale between the first party (the seller) and the second party ( buyer) is only said to sell a plot of land in the sense of not including the land, unless a person has received a grant from the customary owner, the members of the clan cannot disrupt the ownership status of the land that has been handed over to someone through the grant.

A letter of granting to the customary land granted by the customary authority cannot be contested. If someone has held a customary land grant letter, then the party concerned and other parties cannot interfere with the claim and take back the land. In the customary ethics of Minangkabau whoever has received a grant or land specifically designated is not expected to carry out buying and selling, so that communal land is always preserved. Grants from the head of the clan as the customary leader for their niece's grandchildren, for the welfare of his niece's grandchildren in sustaining the economy and the land given was not contested by other parties.

Customary land that has been transferred rights which are mostly in the form of sale and purchase can be registered by the buyer to the Land Office to issue the 
certificate as proof of legal ownership. Communities must meet various requirements before registering land. And do not rule out the process, and must fulfill the requirements.[24]

The issuance of the certificate of communal land results in the loss of the collective (shared) rights attached to the Ulayat land to individual rights. Automatically cause losses to the people themselves where their customary land becomes private / individual land that is no longer subject to the provisions of customary law, and the fading of traditional philosophical values in terms of customary land, both high pusako property, and low pusako property. Customary land which is the pride of the people, will easily be transferred to other parties. At present in Dharmasraya Regency Ulayat lands are rarely found because many have already transferred rights even though they have not been registered.

\section{CONCLUSION}

The existence of the transfer of customary land rights that have not been registered is getting higher, namely in the form of buying and selling, as evidenced by the existence of the communal land as a high inheritance property which has initially declined where the communal land has a social function for its members, but after the transfer of rights in the form of sale and purchase, the communal land rights are lost and the function changes from the original function to social interests / the people become the full rights of the buyer.

The transfer of communal land rights results in the loss of collective (shared) rights attached to customary land to individual rights. Automatically cause loss to the people themselves where their customary land becomes individual / private land that is no longer subject to the provisions of customary law, and the fading of traditional philosophical values in terms of customary land, both high pusako property, and low pusako property. Customary land which is the pride of the people, will easily be transferred to other parties. The rights of the people as the owner of the communal land that has undergone the transfer of rights in the form of buying and selling with a letter of sale and purchase, members of the clan can claim back the communal land that has been bought and sold with that other party, if the transfer of rights is in the form of a grant from the customary owner, then the members of the clan cannot suing the status of land ownership obtained through the transfer of rights on a grant basis

\section{REFERENCES}

[1] I. Aju et al., "Forest Policy and Economics Indonesia' s land reform: Implications for local livelihoods and climate," For. Policy Econ., vol. 108, no. April, p. 101903, 2019, doi: 10.1016/j.forpol.2019.04.007.

[2] Lili Rasjidi dan Ira Tahania, Dasar-Dasar Filsafat dan Teori Hukum. bandung: Citra Aditya Bakti, 2004.

[3] Soerojo wignjodipoero, Pengantar Dan Asas-Asas Hukum Adat. Jakarta: Gunung Agung, 1994.

[4] Sjahmunir, Eksistensi Tanah Ulayat dalam Perundangundangan di Indonesia. Padanh: PPIM, 2000.

[5] HS Salim dan Erlies Septianan Nurbaini, Penerapan Teori Hukum Pada Penelitian Tesis dan Disertasi. Jakarta: Raja Grafindo Persada, 2016

[6] R. A. Wulandari, "No Title," soematera law Rev., vol. 2, no. 2, pp. 221-234, 2019, doi: http://doi.org/10.22216/soumlaw.v2i2.3568.

[7] S. Imam, Hukum Adat Sketsa Asas. Jogjakarta: Liberty, 2004

[8] M. Naim, Menggali Hukum Tanah dan Hukum Waris Minangkabau. Padang: Sri Dharma NV, 1968.

[9] Nasroen. M, Dasar Falsafah Adat Minangkabau. Jakarta: Bulan Bintang, 1971

[10] P. dan R. H. Purbacaraka, Sendi-sendi Hukum Agraria. Jakarta: Ghalia Indonesia, 1993.

[11] Maria.W Sumardjono, Kebijakan Pertanahan;Antara regulasi dan implementasi. Jakarta, 2001.

[12] terjemahan S. P. Ter Haar, Asas-asas dan Susunan hukum Adat. Jakarta: Pradnya Paramita, 1994

[13] Undang-undang no 5 tahun 1960 Tentang Peraturan Dasar Pokok-Pokok Agararia. 1960.

[14] Z. Abubakari, C. Richter, and J. Zevenbergen, "Land Use Policy Exploring the ' implementation gap', in land registration: How it happens that Ghana' s o ffi cial registry contains mainly leaseholds," Land use policy, vol. 78, no. July, pp. 539-554, 2018, doi: 10.1016/j.landusepol.2018.07.011.

[15] S. O. Tito and S. Husin, Analysis of Incentive Factors for Sustainable Land-Use Practices: Lesson Learned From Two Case Studies in West Sumatra, Indonesia, vol. 4. Elsevier Inc., 2017.

[16] M. R. Fisher et al., "Land Use Policy Striving for PAR excellence in land use planning: Multi-stakeholder collaboration on customary forest recognition in Bulukumba , South Sulawesi," Land use policy, no. July 2016, pp. 0-1, 2017, doi: 10.1016/j.landusepol.2017.09.057.

[17] B. Muhammad, Pokok-Pokok hukum adat. Jakarta: Pradnya Paramitha, 1991.

[18] Peraturan Menteri Negara Agraria / Kepala Badan Pertanahan Nasional No 5 Tahun 1999 Tentang Pedoman Penyelesaian Masalah Hak Ulayat Masyarakat Hukum Adat, No Title. 1999.

[19] G. Ayu and M. Suartika, "Territoriality and the market system - Adat land vs . state regulations on land matters in Bali," vol. 31, pp. 167-176, 2007, doi: 10.1016/j.habitatint.2006.11.001.

[20] Alting Husen, Dinamika Hukum Dalam Pengakuan Dan Perlindungan Hak Masyarakat Hukum Adat Atas Tanah (Masa lalu,kini dan Masa Mendatang. Yogyakarta: LaksBang PRESSindo, 2010.

[21] S. S. Maria, Tanah Dalam Perspektif Hak Ekonomi, Sosial dan Budaya. Jakarta: Buku Kompas, 2008.

[22] B. Harsono, Hukum Agraria Indonesia Sejarah Pembentukan Undang-Undang Pokok Agraria Isi dan Pelaksanaan. Jakarta: Djambatan, 2005.

[23] Ardiwilaga Roestandi, Hukum Agraria Indonesia. Jakarta: masa bakti, 1962.

[24] L. Notess et al., "Land Use Policy Community land formalization and company land acquisition procedures: A review of 33 procedures in 15 countries," Land use policy, no. August 2019, p. 104461, 2020, doi: 10.1016/j.landusepol.2020.104461. 